\title{
Contributions with new records to zerconid mite fauna of Turkey (Acari: Zerconidae) ${ }^{1}$
}

Türkiye zerkonid akar faunasına yeni kayıtlarla katkılar (Acari: Zerconidae)

\author{
Mehmet KARACA ${ }^{2^{*}}$
}

\author{
Raşit URHAN ${ }^{3}$
}

\begin{abstract}
Summary
Two zerconid mite species, Zercon sklari Balan and Z. magdae Ivan \& Călugăr, are recorded for the first time from Thrace region of Turkey. Unknown male, deutonymph and protonymph of $Z$. magdae are described and illustrated. Their descriptions are revised from the collected specimens and given with drawings.

Key words: Zercon sklari, Z. magdae, Zerconidae, new records, Turkey

\section{Özet}

İki zerkonid akar türü, Zercon sklari Balan ve Z. magdae Ivan \& Călugăr, Türkiye'den ilk defa Trakya bölgesinden kaydedilmiştir. Z. magdae'nin daha önceden bilinmeyen erkek, deutonimf ve protonimfleri bireyleri tanımlanmış ve çizimleri yapılmıştır. Türlerin örneklerimiz üzerinden gözden geçirilmiş tanımları ve özgün şekilleri verilmiştir.
\end{abstract}

Anahtar sözcükler: Zercon sklari, Z. magdae, Zerconidae, yeni kayıtlar, Türkiye

\footnotetext{
${ }^{1}$ This study has been supported by PAUBAP-2012FBE067 project, Pamukkale University, Denizli

${ }^{2}$ Pamukkale University, Institute of Sciences, Biology Department, Zoology Section, 20070, Kınıklı, Denizli, Turkey

${ }^{3}$ Pamukkale University, Faculty of Arts and Sciences, Biology Department, Kınıklı Campus, 20070, Denizli, Turkey

* Sorumlu yazar (Corresponding author) e-mail: m.karaca_86@hotmail.com

Alınış (Received): 26.09.2014 Kabul ediliş (Accepted): 02.12.2014
} 


\section{Introduction}

Zerconid mites are important members of the soil fauna and they colonise various soil substrates in Northern Hemisphere. They occur in humus and litter of woodlands, in grassland, heatland and among mosses and lichens. These small, predatory mites feed on the eggs, larvae and nymphs of other mites and springtails (Shereef et al., 1984). Only 2 genera, Prozercon and Zercon were known from Turkey. The genus Zercon, based on the number of species in Turkey and worldwide, is the richest in the family Zerconidae. So far, 58 species of this genus have been recorded from Turkey (Urhan, 2012; Urhan \& Öztaş, 2013). As a contribution to knowledge of Zerconidae and to the understanding of the mite faunal richness of Turkey, two new records is reported herein. Of them, $Z$. sklari has been described by Balan (1992) from the steppe zone of Ukraine. On the other hand Z. magdae has been described by Ivan \& Călugăr (2004) on the basis of material collected from Romania and redescibed by Ujvári \& Călugăr (2010).

\section{Materials and Methods}

The mites in soil and litter samples taken from Thrace region were extracted in a Berlese funnel apparatus. Then they were fixed and preserved in $75 \%$ ethanol. The examination and drawing of mites were carried out using an Olympus CX41 microscope with DP25 camera. Materials are deposited in the Department of Zoology of Pamukkale University, Denizli (Turkey). Morphological terminology used in the descriptions follows that of Mašán \& Fend'a (2004). Measurements are given as mean and in micrometers.

\section{Results}

Family: Zerconidae Canestrini, 1891

Genus: Zercon C. L. Koch, 1836

Type-species: Zercon triangularis C. L. Koch, 1836

Zercon sklari Balan, 1992 (Figure 1A, B)

Materials: Edirne province, Keşan, Border province of Edirne-Tekirdağ, closer to Danişment village, 204 m, 08.VI.2013, ô. Sample of litter and soil underlying Pinus pinea from edge of highway.

Male (Figure 1A, B). Idiosoma (excluding gnathosoma) in one specimen; length $327 \mu \mathrm{m}$, width 232 $\mu \mathrm{m}$.

Dorsal side (Figure 1A). 20 pairs of different setae present on podonotum's dorsal side: j-row with 6 pairs, z-row with 2 pairs, s-row with 6 pairs, r-row with 6 pairs. 2 pairs of different setae present on podonotum's ventral side: $p$-row with two pairs (only seta p1 presented on dorsal figure, above seta r1, seta p2 visible on ventral view). All podonotal setae smooth and needle-like (Seta j1 except). Seta j1 is longest seta on podonotum and finely barbed. 20 pairs of different setae present on opisthonotum's dorsal side: J-row with 6 pairs, Z-row with 5 pairs, S-row 2 four pairs, R-row with 7 pairs. All opisthonotal setae smooth, plumose or finely barbed. Setae J1-3, Z1-2, S1-2 and R1-7 smooth and needle-like. Setae $\mathrm{J} 4$ finely barbed, $\mathrm{J} 5$ and $\mathrm{Z3}$ apically plumose, $\mathrm{J} 6$ and $\mathrm{Z} 4$ brush-like and finely barbed, all of them with a hyaline sheath at their ends. Seta Z5 short and finely barbed (seta Z5 only visible on ventral view). None of them not reaching beyond the margins of opisthonotum (Seta $J 6$ except). Seta $J 6$ is longest seta on opisthonotum. Length of opisthonotal setae and distances between setae within longitudinal rows; see Table 1. 

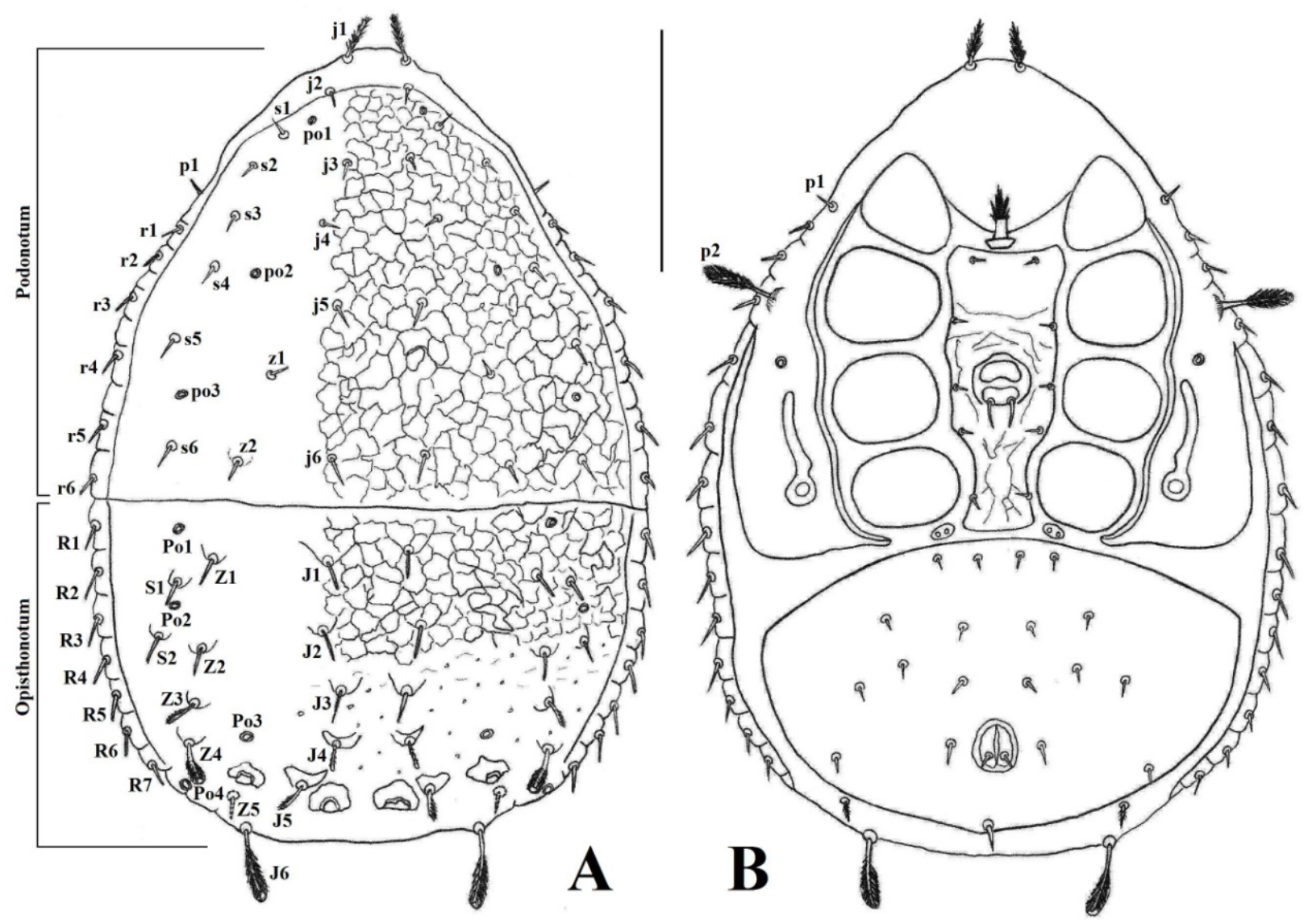

Figure 1. Zercon sklari. A-B: male. A. dorsal view; B. ventral view (scale bar $100 \mu \mathrm{m})$.

Table 1. Lengths of opisthonotal setae and the distances between their bases in J-, Z- and S- rows of male specimen of Zercon sklari (values in micrometers)

\begin{tabular}{|c|c|c|c|c|c|}
\hline Seta & $\hat{\sigma}$ & Seta & o & Seta & $\hat{0}$ \\
\hline $\mathrm{J1}$ & 11 & Z1 & 10 & S1 & 10 \\
\hline $\mathrm{J1}-\mathrm{J} 2$ & 30 & Z1-Z2 & 32 & S1-S2 & 24 \\
\hline $\mathrm{J} 2$ & 11 & Z2 & 12 & S2 & 12 \\
\hline J2-J3 & 26 & Z2-Z3 & 28 & & \\
\hline J3 & 13 & Z3 & 13 & & \\
\hline J3-J4 & 24 & Z3-Z4 & 27 & & \\
\hline $\mathrm{J4}$ & 12 & Z4 & 19 & & \\
\hline J4-J5 & 20 & Z4-Z5 & 35 & & \\
\hline $\mathrm{J5}$ & 10 & Z5 & 19 & & \\
\hline J5-J6 & 33 & & & & \\
\hline $\mathrm{J} 6$ & 31 & & & & \\
\hline J6-J6 & 98 & & & & \\
\hline
\end{tabular}

Pores (Figure 1A). 3 different pores present on podonotum. Pores po1 located inside line connecting j2 and s1, po2 on line connecting j5 and s4, closer to s4, po3 located between s5 and s6. Podonotum covered by tile-like pattern. 4 different pores present on opisthonotum. Pores Po1 located anterolaterally to bases of Z1, Po2 outside line connecting S1 and S2, Po3 on line connecting J5 and Z3, Po4 located outside base of Z4. Dorsal fossae of general size and appearance. Opisthonotum anteriorly covered by tile-like ornamentation, posteriorly smooth.

Ventral side (Figure 1B). Ventral shields' shape and chaetotaxy typical for genus Zercon. Seta p1 smooth, short and needle-like and seta p2 markedly elongated, densely plumose, brush-like and apically 
rounded. Lateral ends of peritremal shield reach R4. Adgenital shields (an important feature of genus Zercon) present with 2 pores. Ventroanal shield with 9 pairs of setae. Anterior margin of ventroanal shield with 2 pairs of setae and postanal seta is single (not pair). All of them smooth, short and needle-like. The shapes of peritremes typical for genus Zercon.

Zercon magdae Ivan \& Călugăr, 2004 (Figure 2A, B, C, D, E)

Materials: Çanakkale province, Gelibolu Peninsula, Kilitbahir, Martyrdom Soğanlıdere, $50 \mathrm{~m}$, 20.I.2013, 8 웅, 6 J, 9 Deutonymphs and 10 Protonymphs. Sample of mosses on surface of soil in graveyard.

Female (Figure 2A, B). Idiosoma (excluding gnathosoma) in the 8 specimens; mean length 409 (396-430) $\mu \mathrm{m}$, mean width 293 (275-305) $\mu \mathrm{m}$.

Dorsal side (Figure 2A). 20 pairs of different setae present on podonotum's dorsal side: j-row with 6 pairs, z-row with 2 pairs, s-row with 6 pairs, r-row with 6 pairs. 2 pairs of different setae present on podonotum's ventral side: p-row with two pairs (seta p1 presented on dorsal figure, above seta r1, seta p2 visible on ventral view). On podonotum, seta j1 densely barbed, setae j2 and r1-6 finely barbed. Remaining setae of podonotum short, smooth and needle-like. $\mathrm{j} 1$ is longest seta on podonotum. 21 pairs of different setae present on opisthonotum's dorsal side: J-row with 6 pairs, Z-row with 5 pairs, S-row 3 four pairs, R-row with 7 pairs. All opisthonotal setae barbed, plumose or brush-like. Setae J1, Z1, S1 and R1-7 finely barbed, J2-6, Z2-5, S2 and S4 densely barbed and hyaline ending. Seta J4 reaching base of following seta (J5) of row. Setae Z1 and S1 similar in shape and length. Setae S3 absent. Setae J6, Z4 and S4 elongated, densely plumose, brush-like, with a hyaline sheath at their end. Setae J6, Z4-5 and S4 reaching beyond the margins of opisthonotum. Average length of opisthonotal setae and distances between setae within longitudinal rows; see Table 2.

Pores (Figure 2A). 3 different pores present on podonotum. Pores po1 near base of s1, po2 located between $\mathrm{j} 4$ and s4, po3 on line connecting s5and s6, closer to s5. Podonotum covered by tile-like pattern. 4 different pores present on opisthonotum. Pores Po1 located anterolaterally to bases of Z1, Po2 outside line connecting Z3 and R5, closer to Z3, Po3 on line connecting J4 and S4, closer to J4, Po4 near bases of S4. Dorsal fossae well sclerotized. Opisthonotum covered by tile-like pattern, central surface with reticulate ornamentation.

Ventral side (Figure 2B). Ventral shields' shape, chaetotaxy and the shapes of peritremes typical for genus Zercon. Seta p1 smooth, short and needle-like and seta p2 markedly elongated, densely plumose, brush-like and apically rounded. Lateral ends of peritremal shield reach R4. Adgenital shields present with 3 pores. Ventroanal shield with 9 pairs of setae. Anterior margin of ventroanal shield with 4 setae and postanal seta is single. All of them smooth, short and needle-like.

Male (Figure 2C). Idiosoma (excluding gnathosoma) in the 6 specimens; mean length 328 (313341) $\mu \mathrm{m}$, mean width 209 (191-219) $\mu \mathrm{m}$.

Dorsal side, ventral side and sculpture of podonotum and opisthonotum basically similar to that of female. On podonotum setae j2-6, z1-2 and s1-6 smooth and needle-like. Setae r1-6 finely barbed and elongated. On opisthonotum all setae' shape similar to females (except setae Z5, S4 and R6-7). Setae R1-5 finely barbed, but R6-7 and Z5 smooth and needle-like. The base of seta Z5 on ventrianal shield. Unlike female individuals, in male specimens seta S4 absent (in female individuals seta S4 present).

Pores (Figure 2C). On podonotum, pores po1 inside line connecting j2 and s1, po2 inside line connectingj4 and s3, closer to s3, po3 inside line connecting j5 and s5, closer to s5. On opisthonotum, pores Po1 located located anterolaterally to bases of Z1, pores Po2 outside line connecting Z3 and S2, and opisthonotum covered by tile-like pattern, as in female individuals. Dorsal cavities of general size and appearance. 


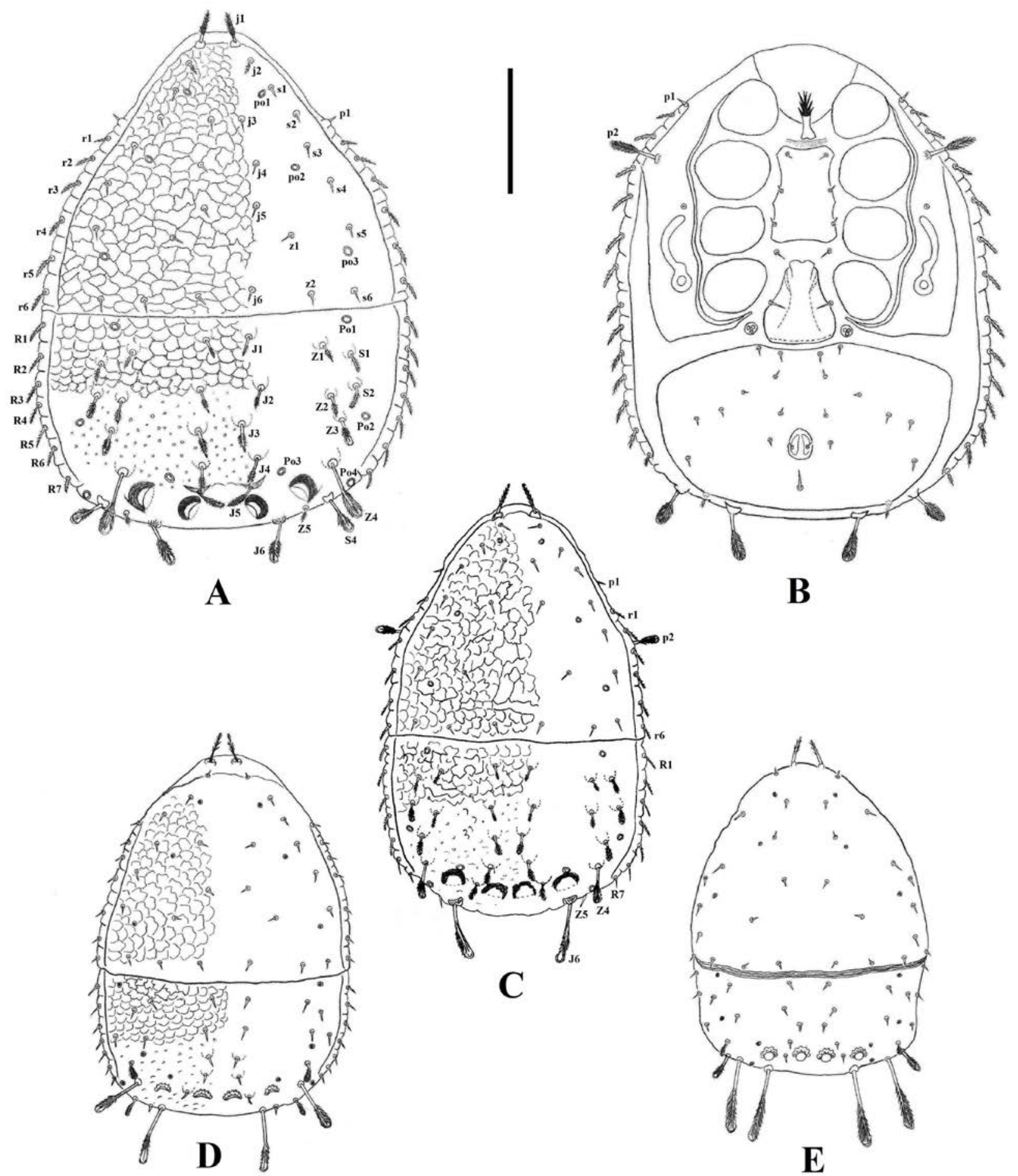

Figure 2. Zercon magdae. A-B: female. A. dorsal view; B. ventral view; C. dorsal view of male; D. dorsal view of deutonymph; E. dorsal view of protonymph (scale bar $100 \mu \mathrm{m})$.

Deutonymph (Figure 2D). Length of idiosoma in 9 deutonymphs 311-334 $\mu \mathrm{m}$, width 191-230 $\mu \mathrm{m}$.

All podonotal setae (except j1) short, smooth and needle-like. Seta j1 elongated, finely barbed and hyaline ending. Opisthonotal setae J1-J5, Z1-2, Z5, S1-2 and R1-R7 smooth and needle-like, setae J6, 
Z3-Z4 and S4 elongated, apically pilose, brush-like and terminated with hyaline ending. Seta Z3 reaching base of following seta (Z4) of row. Setae Z4 reaching lateral margin of opisthonotum and exceeding body edge with $2 / 3$ of their length. On podonotum, pores po1 near base of $j 3$, pores po2 on line connecting j5 and s3, closer to s3 and pores po3 on line connecting z2 and s5, closer to s5. On opisthonotum, pores Po1 outside line connecting Z1 and R1, pores Po2 under base of Z2, pores Po3 inside line connecting J4 and Z3, pores Po4 inside line connecting Z4 and R7. Lengths of opisthonotal setae and distances between setae within rows are as in Table 2.

Protonymph (Figure 2E). Length of idiosoma in 10 protonymphs $220-235 \mu \mathrm{m}$, width $178-185 \mu \mathrm{m}$.

Podonotal setae j1 apically barbed and remaining podonotal setae short, smooth and needle-like. Opisthonotal setae J1- J5, Z1-2 and S1-2 short and smooth, setae J6, Z3-Z4 and S4 thickened, prolonged, apically pilose, and terminated with hyaline ending. Seta Z3 reaching beyond the margins of opisthonotum and base of Seta S4. On podonotum, pores po1 near base of j3, pores po2 on line connecting j4 and s2, closer to j4 and pores po3 inside line connecting j5 and s2, closer to s2. On opisthonotum, pores Po1 outside line connecting Z1 and R1, closer to Z1, pores Po2 on line connecting Z2 and S2, pores Po3 on line connecting J4 and Z3, pores Po4 on line connecting Z4 and J6. Lengths of opisthonotal setae and distances between setae within rows are as in Table 2.

Table 2. Lengths of opisthonotal setae and the distances between their bases in J-, Z- and S- rows of female specimens of Zercon magdae (values as mean, in micrometers) (F: female, M: male, DN: deutonymph, PN: protonymph)

\begin{tabular}{|c|c|c|c|c|c|c|c|c|c|c|c|c|c|c|}
\hline Seta & $\mathrm{F}$ & $\mathrm{M}$ & DN & $\mathrm{PN}$ & Seta & $\mathrm{F}$ & $\mathrm{M}$ & DN & $\mathrm{PN}$ & Seta & $\mathrm{F}$ & $\mathrm{M}$ & DN & $\mathrm{PN}$ \\
\hline $\mathrm{J1}$ & 16 & 14 & 10 & 7 & Z1 & 15 & 11 & 11 & 6 & S1 & 16 & 13 & 9 & 6 \\
\hline J1-J2 & 40 & 34 & 26 & 20 & Z1-Z2 & 41 & 35 & 28 & 22 & S1-S2 & 26 & 20 & 23 & 21 \\
\hline $\mathrm{J} 2$ & 20 & 15 & 11 & 6 & $\mathrm{Z2}$ & 17 & 13 & 10 & 5 & S2 & 19 & 13 & 10 & 6 \\
\hline J2-J3 & 33 & 28 & 28 & 13 & Z2-Z3 & 21 & 21 & 27 & 21 & S2-S3 & - & - & - & - \\
\hline J3 & 16 & 16 & 10 & 6 & Z3 & 20 & 16 & 17 & 9 & S3 & - & - & - & - \\
\hline J3-J4 & 29 & 24 & 16 & 17 & Z3-Z4 & 22 & 23 & 20 & 13 & S3-S4 & - & - & - & - \\
\hline $\mathrm{J4}$ & 23 & 14 & 7 & 5 & Z4 & 49 & 26 & 47 & 54 & S4 & 31 & - & 16 & 20 \\
\hline J4-J5 & 21 & 19 & 19 & 10 & Z4-Z5 & 41 & 27 & 31 & - & & & & & \\
\hline $\mathrm{J5}$ & 24 & 12 & 8 & 5 & Z5 & 11 & 7 & 8 & - & & & & & \\
\hline J5-J6 & 46 & 24 & 21 & 14 & & & & & & & & & & \\
\hline J6 & 35 & 41 & 55 & 56 & & & & & & & & & & \\
\hline J6-J6 & 101 & 94 & 90 & 84 & & & & & & & & & & \\
\hline
\end{tabular}

\section{Remarks}

Most Turkish specimens' setal and morphological characters very similar to both type specimens. The length and width were compared on the basis of the available literature (Table 3). According to Table 3 , our male specimen of $Z$. sklari and female specimens of $Z$. magdae are approximately the same size with type specimens. Also, in Romania specimens of $Z$. magdae, on opisthonotum seta Z4 never reaching beyond the margin of opisthonotum but Turkish specimens it reaching. And seta J3 reach base of seta $\mathrm{J} 4$ in type specimens but in our specimens it does not reach to base of following seta.

Table 3. Length and width intervals of idiosoma of Zercon sklari and Zercon magdae (values in micrometers) (F: female, M: male, $\mathrm{DN}$ : deutonymph, PN: protonymph)

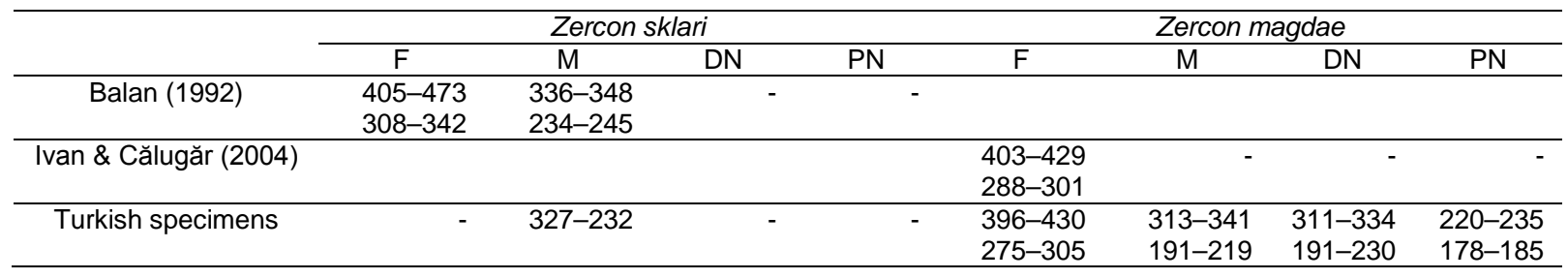


Additionally, unknown male, deutonymph and protonymphs of $Z$. magdae were determined for the first time. With this two new records, number of species increased to 60 of genus Zercon from Turkey (Table 4). Thrace region is regarded as very rich in terms of flora and fauna elements. Similar studies will contribute to determination of zerconid mite fauna of Turkey.

Table 4. Species list of genus Zercon known from Turkey

\begin{tabular}{|c|c|c|c|}
\hline Species & Authorship & Species & Authorship \\
\hline Z. adoxyphes & Błaszak, 1979a & Z. kackaricus* & Urhan \& Ekiz, 2002 \\
\hline Z. agnostus* & Błaszak, 1979a & Z. kallimcii* & Urhan, 2010a \\
\hline Z. alattini* & Urhan, 2011 & Z. karadaghiensis & Balan, 1992a \\
\hline Z. anatolicus* & Urhan, 2008b & Z. kezbaniremae* & Urhan, 2007b \\
\hline Z. andrei & Sellnick, 1958 & Z. lepurus* & Błaszak, 1979a \\
\hline Z. apladellus* & Błaszak, 1979a & Z. longisetosus* & Urhan, 2008c \\
\hline Z. ayyildizi* & Urhan, 1997 & Z. magdae & Ivan \& Călugăr, 2004 \\
\hline Z. beleviensis* & Urhan, 2002 & Z. mehmeturhani* & Urhan, 2009a \\
\hline Z. berlesei & Sellnick, 1958 & Z. mirabilis* & Urhan \& Öztaş, 2013 \\
\hline Z. bulancakensis* & Urhan, 2012 & Z. montanus & Willmann, 1943 \\
\hline Z. bulgaricus & Balogh, 1961 & Z. nemoralis* & Urhan, 2001d \\
\hline Z. burdurensis* & Urhan, 2001a & Z. notabilis* & Błaszak, 1979a \\
\hline Z. cabylus & Athias-Henriot, 1961 & Z. osmaneliensis* & Urhan, 2008c \\
\hline Z. carpathicus & Sellnick, 1958 & z. ozkani* & Urhan \& Ayyıldız, 1994 \\
\hline Z. caucasicus & Błaszak, 1979a & Z. perforatulus & Berlese, 1904 \\
\hline Z. cokelezicus* & Urhan, 2009a & Z. pinicola & Halašková, 1969 \\
\hline Z. colligans & Berlese, 1920 & Z. plumatopilus & Athias-Henriot, 1961 \\
\hline Z. delicatus* & Urhan \& Ekiz, 2002 & Z. quadricavum* & Urhan, 2001c \\
\hline Z. denizliensis* & Urhan, 2011 & Z. salebrosus & Błaszak, 1979b \\
\hline Z. domanicensis* & Urhan, 2010b & Z. salmani* & Urhan, 2002 \\
\hline Z. encarpatus & Athias-Henriot, 1961 & Z. separatus* & Urhan, 2001b \\
\hline Z. foveolatus & Halašková, 1969 & Z. septemporus* & Urhan, 2001d \\
\hline Z. fragilis* & Urhan, 2001c & Z. serratus* & Urhan, 2001a \\
\hline Z. honazicus* & Urhan, 2009b & Z. sklari & Balan, 1992b \\
\hline Z. hungaricus & Sellnick, 1958 & Z. solenites & Haarløv, 1942 \\
\hline Z. huseyini* & Urhan, 2008a & Z. tefenniensis* & Urhan, 2010c \\
\hline Z. ignobilis* & Błaszak, 1979a & Z. trabzonensis* & Urhan, 1997 \\
\hline Z. imperfectsetosus* & Urhan, 2012 & Z. turcicus* & Urhan \& Ayyıldız, 1994 \\
\hline Z. inonuensis* & Urhan, 2007a & Z. uludagicus* & Urhan, 2008a \\
\hline Z. insperatus* & Błaszak, 1979a & Z. yusufi* & Urhan, 2010b \\
\hline
\end{tabular}

* Terra typica of these specimens is in Turkey.

\section{Acknowledgements}

This study was financially supported by the Pamukkale University Scientific Research Projects (PAUBAP), project number: 2012FBE067.

\section{References}

Athias-Henriot, C., 1961. Mesostigmates (Urop.excl.) edaphiques mediterraneens (Acaromorpha, Anactinotrichida). Acarologia, 3: 381-509.

Balan, P. G., 1992a: New mite species of the genus Zercon (Acari, Mesostigmata) from the Crimea. Vestnik Zoologii, 1992 (4): 49-55.

Balan, P. G., 1992b. New species of zerconid mites (Acari, Mesostigmata, Zerconidae) from the steppe zone of Ukraine. Zoologicheskii Zhurnal, 71 (2): 23-29.

Balogh, J., 1961. Zercon bulgaricus spec. nov. (Mesostigmata, Acari). Folia Entomologica Hungarica, 14: 433-435.

Berlese, A., 1904. Acari nuovi. Manipulus II. Redia, 1: 258-280.

Berlese, A., 1920. Centaria V. Redia, 14: 143-195

Błaszak, C., 1979a. Systematic studies on the family Zerconidae, IV. Asian Zerconidae (Acari, Mesostigmata). Acta Zoologica Cracoviensia, 24 (1): 3-112.

Błaszak, C., 1979b. Tunisian Zerconidae (Acari, Gamasida, Zerconidae). Folia Entomologica Hungarica, 32: 13-26. 
Haarløv, N., 1942. A morphologic-systematic-ecological investigation of Acarina and other representatives of the microfauna of the soil around Mørkefjord, Northeast Greenland. Meddelels. Grønl. 128: 1-71 + Plates 1-3.

Halašková, V., 1969. Zerconidae of Czechoslovakia (Acari: Mesostigmata). Acta Universitatis Carolinae-Biologica, 34: 175-352.

Ivan, O. A. \& A. Călugăr, 2004. Studiul Familiilor Zerconidae Canestrini, 1891 si Scheloribatidae Grandjean, 1933 (Acari, Gamasina, Oribatida): Morfologia, Taxonomia, Ecologia si Raspandirea Speciilor Din Fauna Romaniei. Revista de Politica Stiintei si Scientometric (Numar special), 54 pp.

Mašán, P. \& P. Fend'a, 2004. Zerconid Mites of Slovakia (Acari, Mesostigmata, Zerconidae). Slovak Academy of Sciences, Institute of Zoology, Bratislava, $238 \mathrm{pp}$.

Sellnick, M., 1958. Die familie Zerconidae Berlese. Acta Zoologica Academiae Scientiarum Hungaricae, 3: $313-368$.

Shereef, G. M., M. A. Afifi \& S. H. O. El Bishlawy, 1984. Description, life cycle and feeding habitats of Zercon adalicus n. sp. (Acari, Gamasida, Zerconidae). Bulletin of Faculty of Agriculture, Cairo University, 35: 1765-1774.

Ujvári, Z. \& A. Călugăr, 2010. New zerconid mite species (Acari: Mesostigmata: Zerconidae) from Romania. Acta Zoologica Academiae Scientiarum Hungaricae, 56 (3): 235-255.

Urhan, R., 1997. Two new species of mites of the family Zerconidae from Turkey (Acari, Mesostigmata). Genus, 8 (34): 735-742.

Urhan, R., 2001a. New species of zerconid mites (Acari, Gamasida, Zerconidae) from Turkey. Acarologia, $42: 67-73$.

Urhan, R., 2001b. A new species of the genus Zercon Koch (Acari, Gamasida, Zerconidae) from Turkey. Zoology in the Middle East, 22: 107-112.

Urhan, R., 2001c. Descriptions of two new species of the genus Zercon Koch (Acari, Gamasida, Zerconidae) from Turkey. Zoology in the Middle East, 23: 107-112.

Urhan, R., 2001d. Two new species of the genus Zercon Koch from Turkey (Acari, Gamasida, Zerconidae). Genus, 12 (4): 589-597.

Urhan, R., 2002. New zerconid mites (Acari: Gamasida: Zerconidae) from Turkey. Journal of Natural History, 36: 2127-2138.

Urhan, R., 2007a. Zercon inonuensis n. sp. (Acari, Zerconidae) from Turkey. Zoology in the Middle East, 42: $117-120$.

Urhan, R., 2007b. A new species of the genus Zercon (Acari, Zerconidae) from Turkey. Zootaxa, 1463: 47-54.

Urhan, R., 2008a. Two new species of Zercon (Acari: Zerconidae) from Turkey. Biologia, 63 (3): 395-401.

Urhan, R., 2008b. Zercon anatolicus, a new species of zerconid mites (Acari: Mesostigmata: Zerconidae) from Turkey. Annales Zoologici, 58 (2): 255-260.

Urhan, R., 2008c. Two new species of Zercon C. L. Koch (Acari, Mesostigmata, Zerconidae) from Turkey: Zercon longisetosus sp. n. and Zercon osmaneliensis sp. n. Turkish Journal of Zoology, 32: 217-224.

Urhan, R., 2009a. Zerconid mites (Acari, Mesostigmata, and Zerconidae) from Turkey. Turkish Journal of Zoology, 33: 321-329.

Urhan, R., 2009b. Zercon honazicus sp. n., a new species of mite from Turkey. Zoology in the Middle East, 48: 97100.

Urhan, R., 2010a. Zercon kallimcii sp. n., a new species of zerconid mite (Acari, Zerconidae) from Turkey. Turkish Journal of Zoology, 34: 169-176.

Urhan, R., 2010b. Two new species of Zercon (Acari: Zerconidae) from Turkey. Biologia, 65 (1): 92-98.

Urhan, R., 2010c. Two new species of zerconid mites from Turkey. Zoology in the Middle East, 50: 111-118.

Urhan, R., 2011. Two new species of zerconid mites (Acari, Mesostigmata) from Honaz Mountain National Park (Turkey). Turkish Journal of Zoology, 35 (2): 163-174.

Urhan, R., 2012. Two new species of Zercon C. L. Koch, 1836 from Turkey. Zoology in the Middle East, 56: $125-132$.

Urhan, R. \& N. Ayyıldız, 1994. Two new species of the genus Zercon Koch (Acari, Zerconidae) from Turkey. International Journal of Acarology, 19 (4): 335-339. 
Urhan, R. \& A. N. Ekiz, 2002. Systematic studies on zerconid mites (Acari: Gamasida: Zerconidae) of Turkey. Acta Zoologica Academiae Scientiarum Hungaricae, 48 (3): 225-235.

Urhan, R. \& M. Öztaş, 2013. A new species of mite from Turkey: Zercon mirabilis sp. n. (Acari, Zerconidae). Zoology in the Middle East, 59 (1): 84-88.

Willmann, C., 1943. Neue milben aus den östlichen Alpen. Sitzber. Öst. Akad. Wiss. Math.-naturw. KI. I., 162 (6): 449-519. 